\title{
What Courses Should Law Students Take? Harvard's Largest Employers Weigh In
}

\section{Citation}

John C. Coates, Jesse M. Fried \& Kathryn Spier, What Courses Should Law Students Take? Harvard's Largest Employers Weigh In (HLS Program on the Legal Profession, Research Paper No. 2014-12, Harvard Public Law Working Paper No. 14-20, 2014).

\section{Published Version}

http://blogs.law.harvard.edu/hnmcp/files/2014/02/What-courses-should-law-students-takeHarvard-largest-employers-weigh-in.pdf

\section{Permanent link}

http://nrs.harvard.edu/urn-3:HUL.InstRepos:12911341

\section{Terms of Use}

This article was downloaded from Harvard University's DASH repository, and is made available under the terms and conditions applicable to Open Access Policy Articles, as set forth at http:// nrs.harvard.edu/urn-3:HUL.InstRepos:dash.current.terms-of-use\#OAP

\section{Share Your Story}

The Harvard community has made this article openly available.

Please share how this access benefits you. Submit a story.

\section{Accessibility}




\title{
What Courses Should LaW Students TAKe? HaRVARD'S LARGEST EMPLOYERS WEIGH IN
}

\author{
John Coates* \\ Jesse Fried ${ }^{\dagger}$ \\ Kathryn Spier
}

February 17, 2014

\begin{abstract}
We report the results of an online survey, conducted on behalf of Harvard Law School, of 124 practicing attorneys at major law firms. The survey had two main objectives: (1) to assist students in selecting courses by providing them with data about the relative importance of courses; and (2) to provide faculty with information about how to improve the curriculum and best advise students. The most salient result is that students were strongly advised to study accounting and financial statement analysis, as well as corporate finance. These subject areas were viewed as particularly valuable, not only for corporate/transactional lawyers, but also for litigators. Intriguingly, non-traditional courses and skills, such as business strategy and teamwork, are seen as more important than many traditional courses and skills.
\end{abstract}

\footnotetext{
* John F. Cogan, Jr. Professor of Law and Economics, Harvard Law School.

${ }^{\dagger}$ Professor of Law, Harvard Law School.

* Domenico de Sole Professor of Law, Harvard Law School. We are extremely grateful to Michael Waks JD '14 for his valuable assistance in carrying out the survey, and tabulating and reporting its results.
} 


\section{INTRODUCTION}

During Spring and Summer 2013, we conducted an online survey of 124 practicing attorneys at major law firms on behalf of Harvard Law School (HLS) to learn more about how HLS can better advise and train its students.

The survey had two main objectives: (1) to assist HLS students in selecting courses by providing them with data about the relative importance of various currently-offered HLS courses; and (2) to provide HLS faculty with information about how to improve the curriculum and how to best advise HLS students. The survey focused heavily (but not exclusively) on business-methods courses (e.g., accounting), based on informal feedback from alumni and other practitioners that students should acquire basic business-methods skills while in law school. We created the survey with help from Dean Martha Minow and over a dozen other HLS faculty. ${ }^{1}$

The 124 attorneys participating in the survey come from the 11 largest employers of HLS students over the last several years: Ropes and Gray, Davis Polk, Skadden Arps, Latham \& Watkins, Kirkland \& Ellis, Cravath, Cleary Gottlieb, WilmerHale, Covington Burling, Gibson Dunn, and Sidley Austin. For the survey, each firm was asked to recruit attorneys from a range of positions and practice areas in the firm (junior associate, senior associate, junior partner, and senior partner; litigation, transactional, and regulatory). The surveyed attorneys thus represent varying amounts and kinds of practice experience.

Section A describes feedback from the survey regarding course selection. Section B reports feedback regarding the skills and knowledge bases that students should acquire while at HLS. Section C summarizes.

\section{A. What Courses Should HLS Students Take?}

We turn first to attorney feedback on which business-methods courses students should take, and then to feedback about other courses.

\section{Business-Methods Course Recommendations}

We asked respondents to rate the usefulness of seven business-methods classes currently offered as part of the HLS curriculum on a scale of 1 ("not at all useful") to 5 ("extremely useful"):

- "Accounting and Financial Reporting"

- "Corporate Finance"

- "Negotiation Workshop"

- "Business Strategy for Lawyers"

\footnotetext{
${ }^{1}$ A copy of the survey can be found in Appendix B.
} 
- "Analytical Methods for Lawyers"

- "Leadership in Law Firms"

- "Statistical Analysis/Quantitative Analysis"

Among all respondents, "Accounting and Financial Reporting" and "Corporate Finance" received the highest ratings of with overall scores of 4.38 and 4.21 , respectively. ${ }^{2}$ We also divide responses by practice area: corporate/transactional vs. litigation. The scores for "Accounting and Financial Reporting" and "Corporate Finance" given by attorneys in corporate/transactional practice were higher than the overall scores $(4.62 \text { and } 4.66)^{3}$ and those given by attorneys in litigation practice only were lower (4.15 and 3.84). ${ }^{4}$ For both practice areas, these two classes were the highest ranked of the seven courses listed. ${ }^{5}$

We also asked attorneys to choose, from the above list of seven courses, the three most important business-methods courses. "Accounting and Financial Reporting" and "Corporate Finance" also topped that list. Overall, 83\% of attorneys advised students to take "Accounting and Financial Reporting," and 68\% advised students to take "Corporate Finance." Among corporate lawyers, 86\% recommended "Accounting and Financial Reporting" and 78\% recommended "Corporate Finance." Among litigators, $85 \%$ of attorneys advised students to take "Accounting and Financial Reporting," with 56\% recommending "Corporate Finance."

Ranking below "Accounting and Financial Reporting" and "Corporate Finance" in usefulness were the "Negotiation Workshop," "Business Strategy for Lawyers," and "Analytical Methods for Lawyers," which received overall scores of 3.77, 3.59, and 3.46, respectively on the 1-to-5 scale. ${ }^{6}$ When asked to list the three most useful business-method courses, $46 \%$ of attorneys chose "Negotiation Workshop," 41\% chose "Business Strategy," and 32\% chose "Analytical Methods." The scores tended to be somewhat lower for attorneys in litigation practice and higher for lawyers in corporate/transactional practice. ${ }^{7}$

In response to an open-ended question at the end of the survey, attorneys reiterated the importance of business-methods courses. Several corporate partners emphasized Corporate Finance, and lawyers from all departments (corporate, litigation and regulatory) emphasized Accounting. A young corporate partner at a top national firm wrote that it was "critical to obtain a basic background in accounting and finance" for associates going into transactional or tax

\footnotetext{
2 Appendix A.1.

${ }^{3}$ Appendix A.3.

${ }^{4}$ Appendix A.2.

${ }^{5}$ Because we received only 22 responses from attorneys in regulatory practice, we do not report separate results for this practice area.

${ }^{6}$ Appendix A1.

7 Appendices A2 and A3. "Statistical/Quantitative Analysis" and "Leadership in Law Firms" received overall scores of 2.88 and 2.72, respectively, in Question \#1, and were identified by $15 \%$ and $10 \%$ of attorneys in Question \#2.

These courses latter two courses received stronger support from attorneys in litigation practice, with $25 \%$ advising students to take "Statistical/Quantitative Analysis" and 17\% to take "Leadership in Law Firms," and lower scores in the corporate/transactional practice area.
} 
practice, while a litigation partner at the same firm suggested that all litigation associates would do well to have taken Accounting. A corporate partner with 30 years of experience in a top New York firm noted:

The biggest deficiency from my HLS education (many years ago) was the lack of any serious education in Accounting. All that was offered was a half-semester course in basic double-entry bookkeeping, which was a joke. Yet, Accounting is absolutely central to commercial life and for lawyers whose practice involves commerce, it is essential.

A regulatory associate at another top New York firm stressed that Accounting and Corporate Finance were particularly important for law students without business backgrounds:

I had no business background because my undergraduate studies focused on the humanities, and [I] can't imagine how much more difficult it might have been had I started working here without having taken some of the more business-oriented classes in law school (corporate finance, corporations, and every tax class offered).

One self-identified Yale Law graduate with five to ten years of experience in a corporate department wrote:

What most matters is that students (i) develop deep analytical abilities, and (ii) can navigate accounting materials and technical literature (e.g., figuring out how the economics are working within a complex fund structure).

This commenter suggested, however, that Accounting and Corporate Finance were useful as "vocabulary" and to "help students identify issues," but emphasized there was "value to having students develop their analytical abilities both within those more practice-focused realms and within areas of more academic interest (e.g., Islamic law)."

The importance of these business-methods courses is also made clear by firms' extensive use of training programs to teach accounting and finance to attorneys. Overall, $72 \%$ of the respondents reported that their own firms offer in-house training in the business-methods area. ${ }^{8}$ Most of these programs focus, at least in part, on accounting, financial reporting, and valuation. In addition, almost $30 \%$ of the respondents have taken CLE or supplemental courses outside their firms in accounting, financial reporting, and/or valuation. ${ }^{9}$

To be sure, there were dissenting voices in the open-ended comments concerning the importance of business-methods courses. A corporate associate with five to ten years of experience at a New York law firm wrote: "It's [not] necessary to take a ton of business courses ... Harvard students are bright enough to pick up what they need to know in the first year." Others emphasized the importance of practice area in determining in retrospect what courses were most valuable.

\footnotetext{
${ }^{8}$ Appendix B, Question 7(c).

${ }^{9}$ Appendix B, Question 7(a).
} 


\section{Non-"Business Methods" Course Recommendations}

In addition to asking attorneys about which business-methods courses students should take, we asked them to indicate which courses both in and outside the area of "Business Organizations, Commercial Law, and Finance" would be most useful to students.

\section{a. Business Organization, Commercial Law, and Finance ("BO") Courses}

Respondents were asked to indicate the usefulness of HLS courses currently taught by regular Harvard faculty in the area of "Business Organization, Commercial Law, and Finance." Three courses received overall scores above 4.00: "Corporations" (4.61), "Mergers \& Acquisitions" (4.33), and "Securities Regulation" (4.22). ${ }^{10}$ Many others received scores of over a 3.00: "Capital Market Regulation" (3.92), "Securities Litigation" (3.89), "Taxation (Corporate)" (3.83), "Bankruptcy/Corporate Reorganization" (3.77), "Antitrust" (3.59), "Secured Transactions (Article 9)" (3.51), and “Taxation (Individual)" (3.05). ${ }^{11}$

The rankings of the courses and the overall assessments of importance differed somewhat between practice areas. In the litigation practice area, the top three courses were "Corporations" (4.56), "Securities Litigation" (4.27), and "Securities Regulation" (4.02). ${ }^{12}$ In the corporate/transactional practice area, the top three were "Corporations" (4.78), "Mergers \& Acquisitions" (4.70) and "Securities Regulation" (4.48). ${ }^{13}$ However, "Corporations" and "Securities Regulation" appear in the top three courses for both the litigation and corporate/transactional areas.

In response to the open-ended question, several respondents specifically mentioned Corporations and Securities Regulation. "Everyone coming to work at a Wall Street firm should take securities regulation, corporations and ... taxation" wrote one corporate associate with five to ten years of experience at a New York law firm. Another wrote: "Large firms represent large businesses. I think it makes sense for students interested in working for large firms - whether in the corporate or litigation area-to take business-related law courses." Many also emphasized that the best course selections depended upon the practice area into which a student was headed.

\section{b. Non-BO Courses}

Among offerings outside "Business Organization, Commercial Law, and Finance," no course received an overall score of above 4.00. However, a number of courses received scores above a 3.00. In descending order, among all attorneys, these were "Evidence" (3.57),

\footnotetext{
${ }_{11}^{10}$ Appendix A1.

11 Appendix A1.

12 Appendix A2.

${ }^{13}$ Appendix A3.
} 
"Intellectual Property Law" (3.55), "Federal Courts" (3.50), “Administrative Law" (3.44), "Patent Law" (3.23), Conflict of Laws (3.06), and "Copyright Law (3.02). ${ }^{14}$

However, for these non-business law courses, the rankings of the courses and the overall assessments of importance differed significantly between practice areas. In the litigation practice area, "Evidence" (4.50), "Federal Courts" (4.40), and "Administrative Law" (3.87) received the highest scores. ${ }^{15}$ In the corporate/transactional practice area, "Intellectual Property Law" (3.50), "Patent Law" (3.20) and "Copyright Law" (3.10) received the highest scores. ${ }^{16}$

\section{B. What Skills/Knowledge Bases Should Students Acquire?}

HLS students seeking to improve their capabilities through lecture courses, clinics, and extra-curricular activities should be aware of what skills and knowledge bases are considered most important by employers. We thus asked attorneys to indicate, on a scale of 1 to 5 , the importance of several knowledge bases and skills for their associates:

- "Accounting/Financial Statement Analysis"

- "Teamwork"

- "Financial Markets/Products"

- "Negotiations"

- "Business Strategy/Industry Analysis"

- "Statistical/Quantitative Analysis"

- "Legal Services Industry"

"Accounting/Financial Statement Analysis" topped that list, with a score of 4.30 and "Teamwork" was rated the second most important skill with an overall score of 4.28. In third place was "Financial Markets/Products" (4.00); in fourth was "Negotiations" (3.85); in fifth was "Business Strategy/Industry Analysis" (3.68). ${ }^{17}$ Taken together, these results suggest that law firms value softer skills and institutional knowledge as well as rigorous analytical skills.

These scores were reflected in the open-ended comments as well. A corporate partner with ten to twenty years of experience suggested that "law firm leadership / business of law offerings are quite intriguing" and "could [give] HLS grads a leg up on a key determining factor in evaluating success in private practice - is the attorney adding value for the client ...?" A litigation associate wrote:

I have to say that, surprisingly, my $3 \mathrm{~L}$ class on large law firms was one of the most honest and helpful classes that I took, even though I'm much more of a core, lecture-based, bar-exam course type person generally.

\footnotetext{
${ }_{15}^{14}$ Appendix A1.

${ }^{15}$ Appendix A2.

${ }^{16}$ Appendix A3.

${ }^{17}$ The last two were Statistical/Quantitative Analysis (2.96) and Legal Services Industry (2.85).
} 
Among the open-ended comments, litigators tended to single out "writing" or "persuasive writing" as a key skill that can be lacking in new associates. Other respondents indicated that students should work on communications skills (public speaking and presentations). One attorney suggested that students interested in working in a large New York firm read the Wall Street Journal regularly "so that they come to work with a sense of the context of deals as well as current issues and trends."

A litigation partner with ten to twenty years of experience also commented that "people skills" are "underrepresented" among new associates, and a corporate associate wrote that students would do well to take courses containing "leadership/teamwork training through group projects."

Again, there were some dissenters. A litigation associate noted that "certain skills are best learned in practice," and a litigation partner with five to ten years of experience wrote:

I am skeptical that more 'skills' training in law school can really prepare students ... [C]linical education (or even the skills classes described in this [survey]) are not similar enough to what we do to really help ... much ... I am a proponent of reducing law school to two years.

Finally, quite a few attorneys suggested that existing courses give more weight to transaction planning and documentation and less weight to caselaw.

Several other corporate associates stressed the importance of hands-on experience with contracts (M\&A contracts and loan agreements) and SEC filings, writing "Also, ... it could be hugely helpful ... if in the context of this type of workshop or another class, you could introduce students to the actual legal documents that govern these transactions...."

Another corporate associate with five to ten years of experience in a national law firm suggested that courses should:

Use real-life examples of what the process of a deal is from signing of letter of intent/memorandum of understanding until close, including due diligence process, negotiation and drafting.

In the same spirit, a corporate associate at a national law firm suggested that Negotiations could be taught around a potential deal:

The most useful thing ... to prepare ... to be a corporate lawyer would be ... the negotiation workshop, but instead of negotiation simulations, it would be deal (public and/or private) simulations. Having students role play ... what it is like to be on the buy-side, sell-side or financing side of transactions would be very helpful.

The importance of offering courses better connected to actual practice was repeatedly emphasized. A corporate associate with five to ten years of experience at a New York law firm commented: 
As an HLS alum who knew I wanted to practice corporate law before I came to law school, I was disappointed [that] ... 75\% of the classes still seemed to have nothing to do with corporate law or the real-world practice of law firms. I took ... business strategy class one of the first semesters it was offered (I was a 3L), and it was wildly oversubscribed. I wish there had been more classes like that while I was there.

\section{Summary}

The most salient result from the survey is that students should learn accounting and financial statement analysis, as well as corporate finance. These two subject areas are viewed as particularly valuable both for lawyers in litigation and lawyers working in corporate/transactional practice areas. 


\section{Appendix A: Charts for Student Advising}

This appendix presents the results from the Harvard Law School's Employer Survey (2013) that are relevant for general student advising. Appendix $\mathrm{A} 1$ includes the responses from all attorneys $(\mathrm{N}=124)$. Appendices A2 and A3 break out the responses from attorneys in the litigation $(\mathrm{N}=52)$ and corporate/transactional practice $(\mathrm{N}=50)$ areas, respectively. ${ }^{18}$

\section{Appendix A1: General Results for All Practice Areas $(\mathrm{N}=124)$}

\section{Question \#1: Rating HLS Business Methods Courses}

HLS has a variety of business methods course offerings that are geared towards students who have had little or no exposure to these areas. For each of the following existing HLS classes, please indicate how useful the course would be for an associate to have taken. $(1=$ Not at all Useful; $3=$ Somewhat Useful; 5 $=$ Extremely Useful)

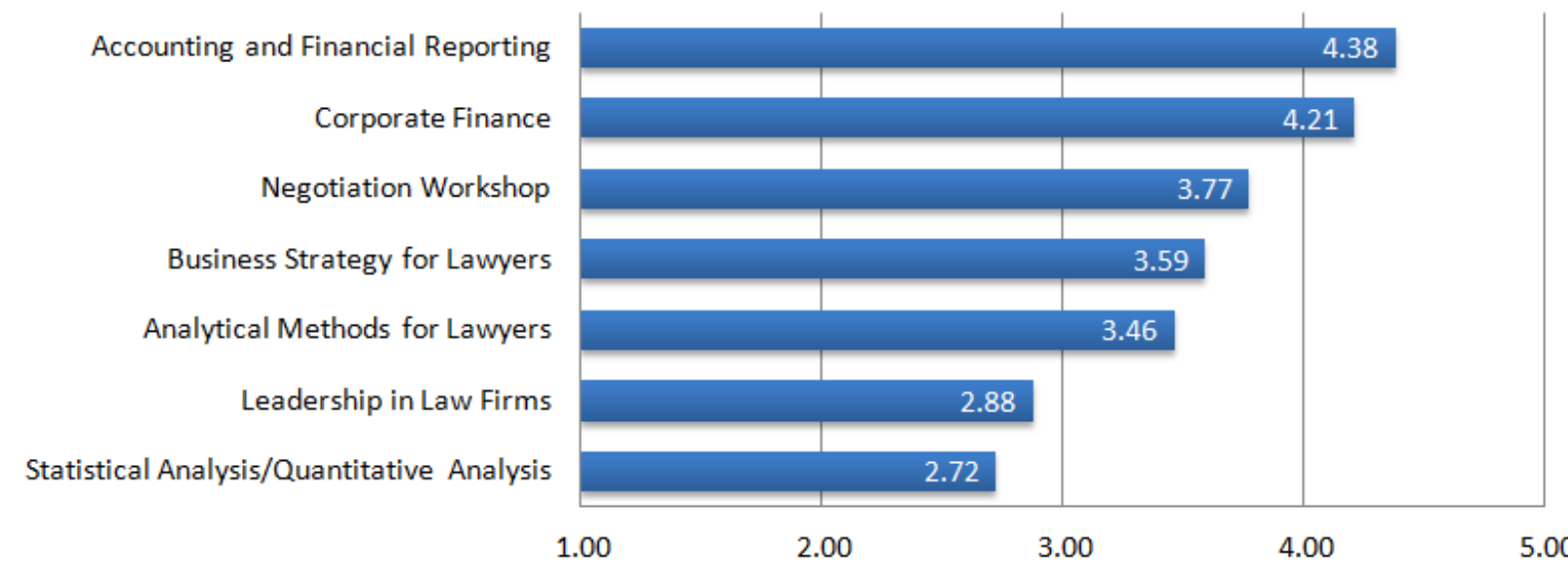

\section{Question \#2: Ranking HLS Business-Methods Courses}

If you were advising an HLS student about which business methods class (or classes) to take, which three of the above classes would you suggest?

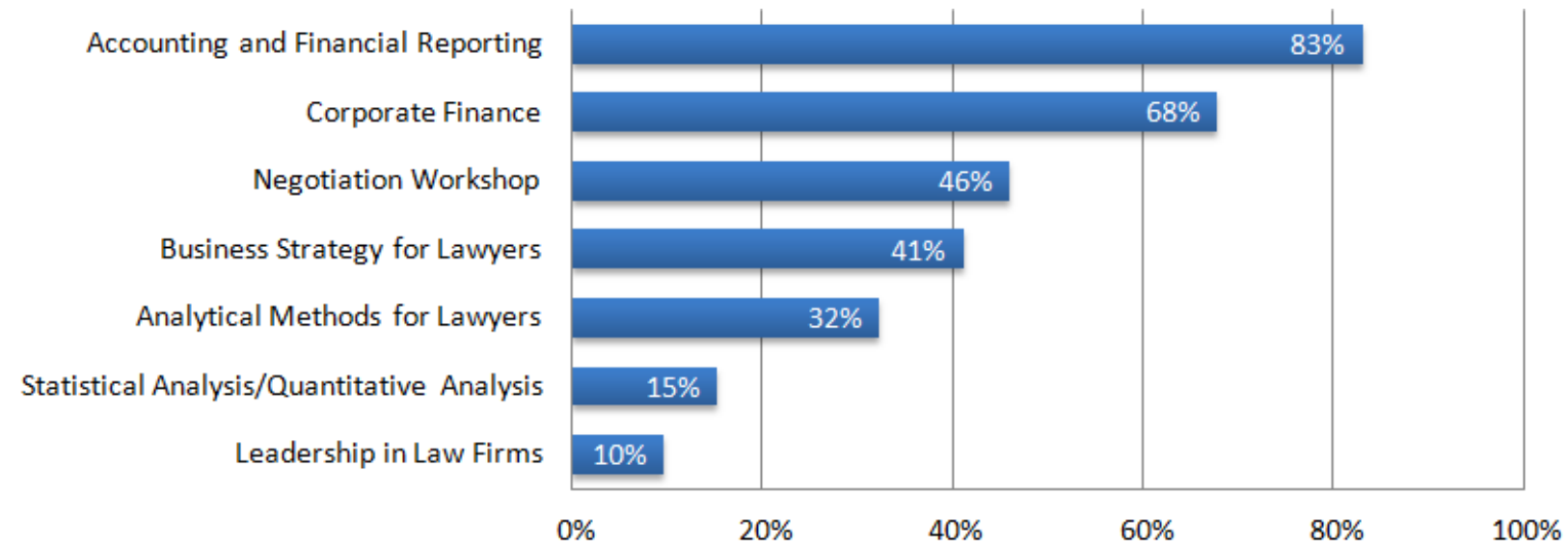

\footnotetext{
${ }^{18} \mathrm{We}$ do not present separate charts for the tax/regulatory practice area $(\mathrm{N}=22)$.
} 


\section{Appendix A1: General Results for All Practice Areas $(\mathrm{N}=124)$}

\section{Question \#3: Rating Knowledge/Skills Bases}

Please indicate how important the following knowledge bases/skills are for your associates. $(1=$ Not at all Useful; 3 = Somewhat Useful; 5 = Extremely Useful)

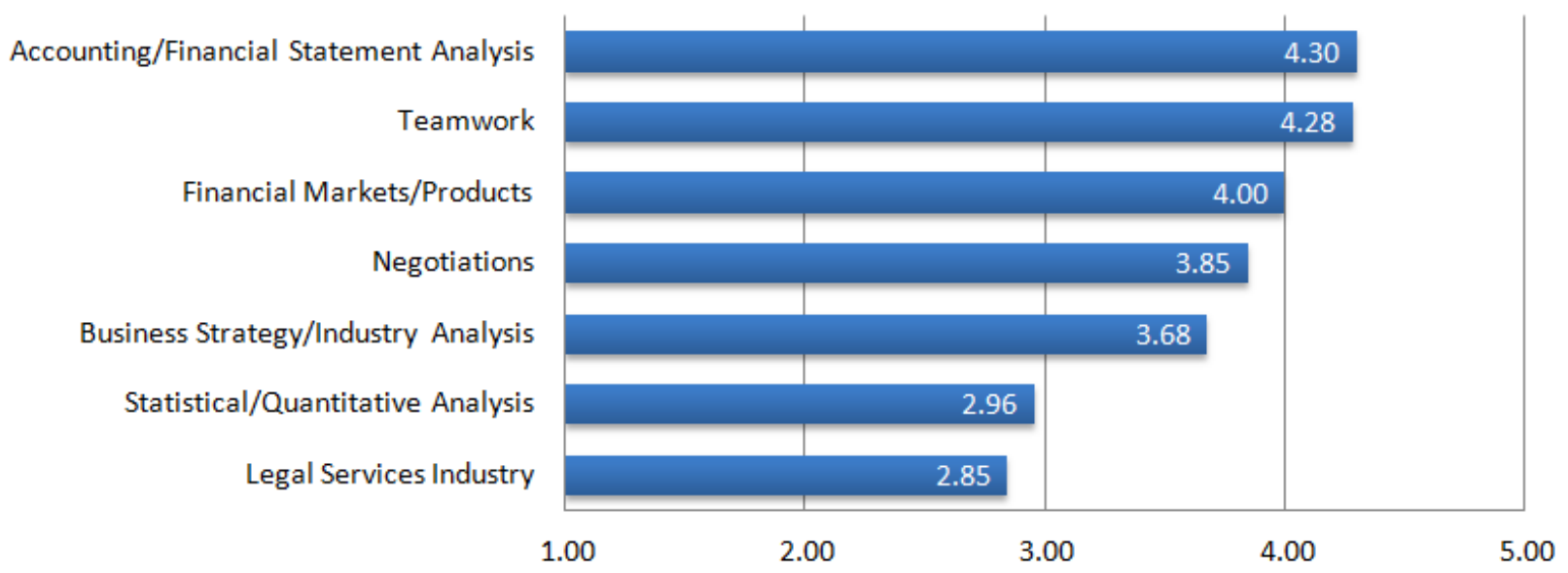

\section{Question \#5: Rating Business Organizations Courses}

Below is a list of courses taught by regular Harvard faculty in the area of Business Organizations, Commercial Law, and Finance during the academic year 2012-2013. The list excludes all of the businessmethods courses described in the previous questions. Please indicate how useful it would be to an associate to have taken these courses. ( $1=$ Not at all Useful; $3=$ Somewhat Useful; $5=$ Extremely Useful)

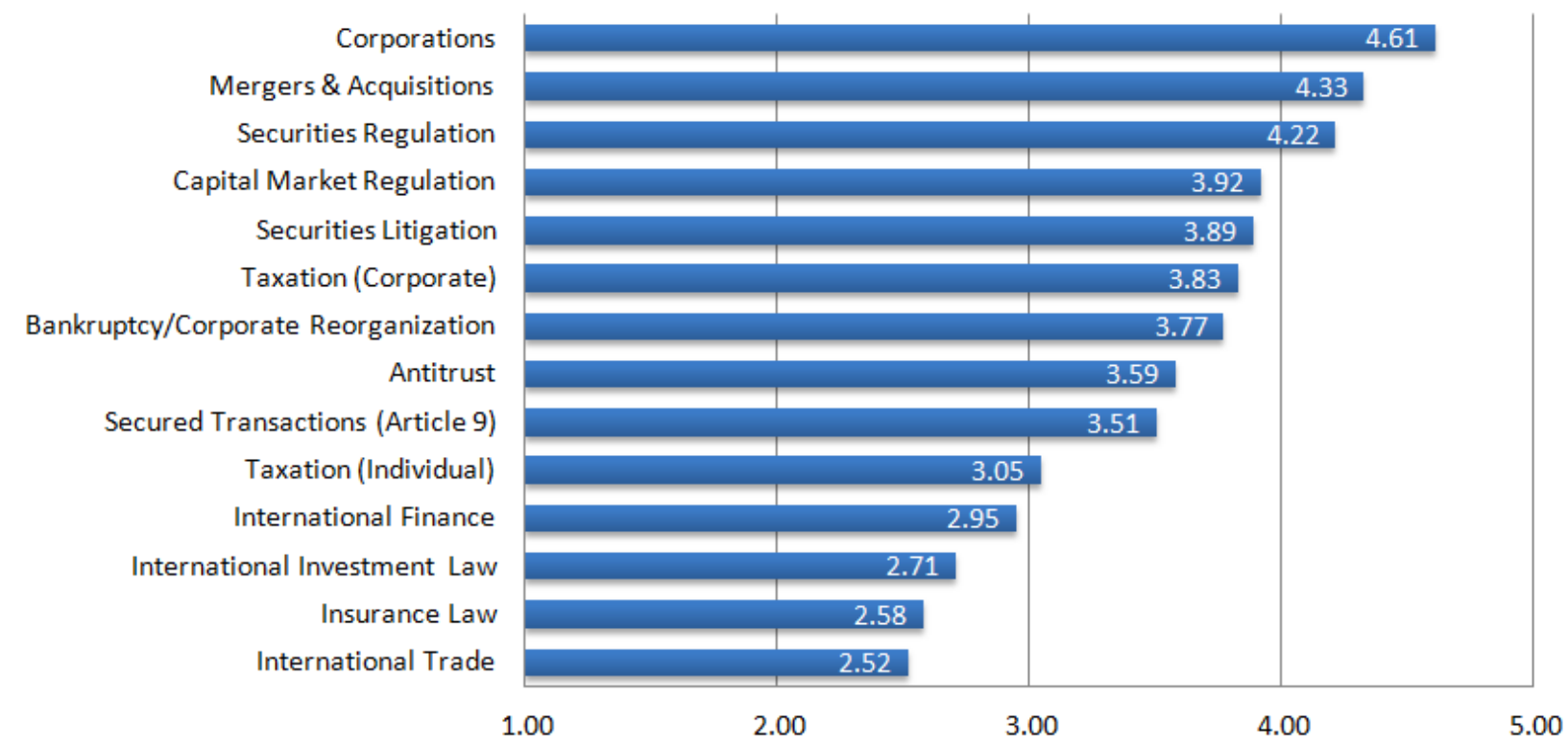




\section{Appendix A1: General Results for All Practice Areas $(\mathrm{N}=124)$}

\section{Question \#6: Rating Non-BO Courses}

Below is a list of elective courses taught by regular Harvard faculty outside the area of Business Organization, Commercial Law, and Finance. Please indicate how useful it would be to an associate to have taken these elective courses. $(1=$ Not at all Useful; $3=$ Somewhat Useful; $5=$ Extremely Useful $)$

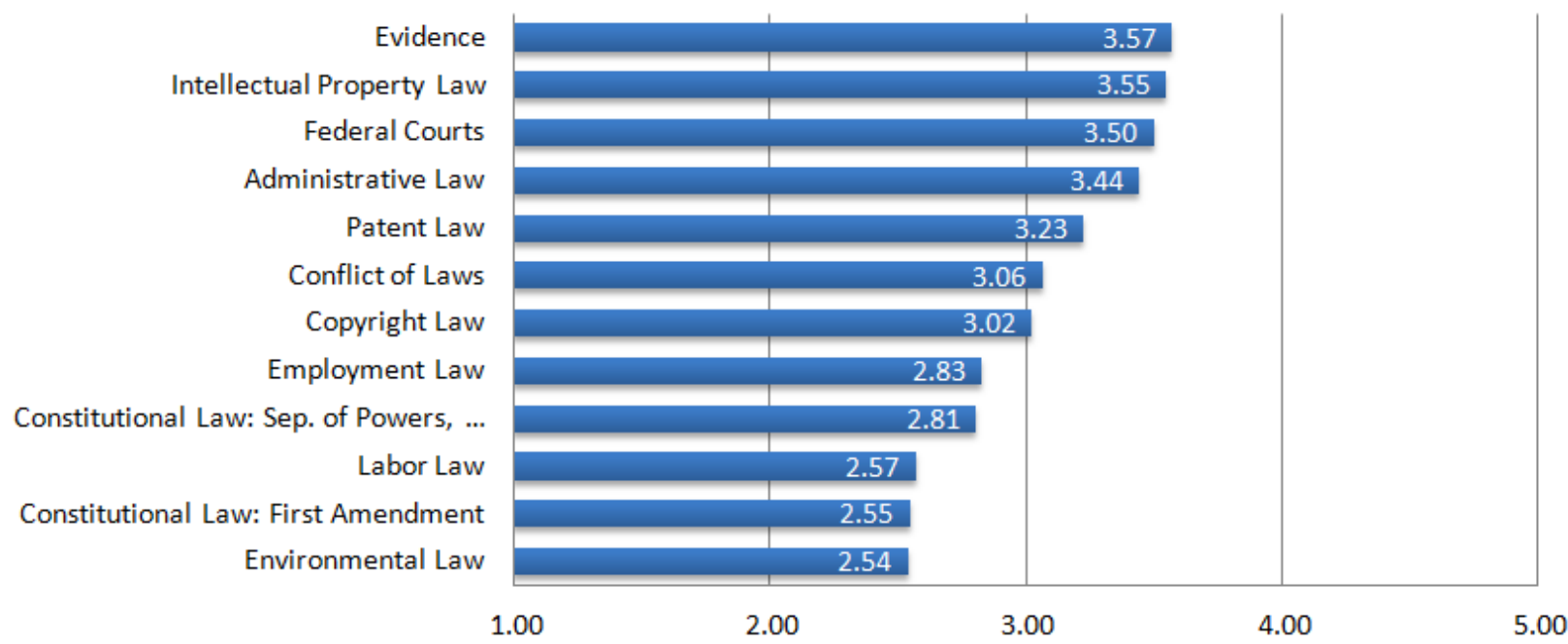




\section{Appendix A2: Litigation Practice Only $(\mathrm{N}=52)$}

\section{Question \#1: Rating Business Methods Courses}

HLS has a variety of business methods course offerings that are geared towards students who have had little or no exposure to these areas. For each of the following existing HLS classes, please indicate how useful the course would be for an associate to have taken. $(1=$ Not at all Useful; 3 = Somewhat Useful; 5 $=$ Extremely Useful)

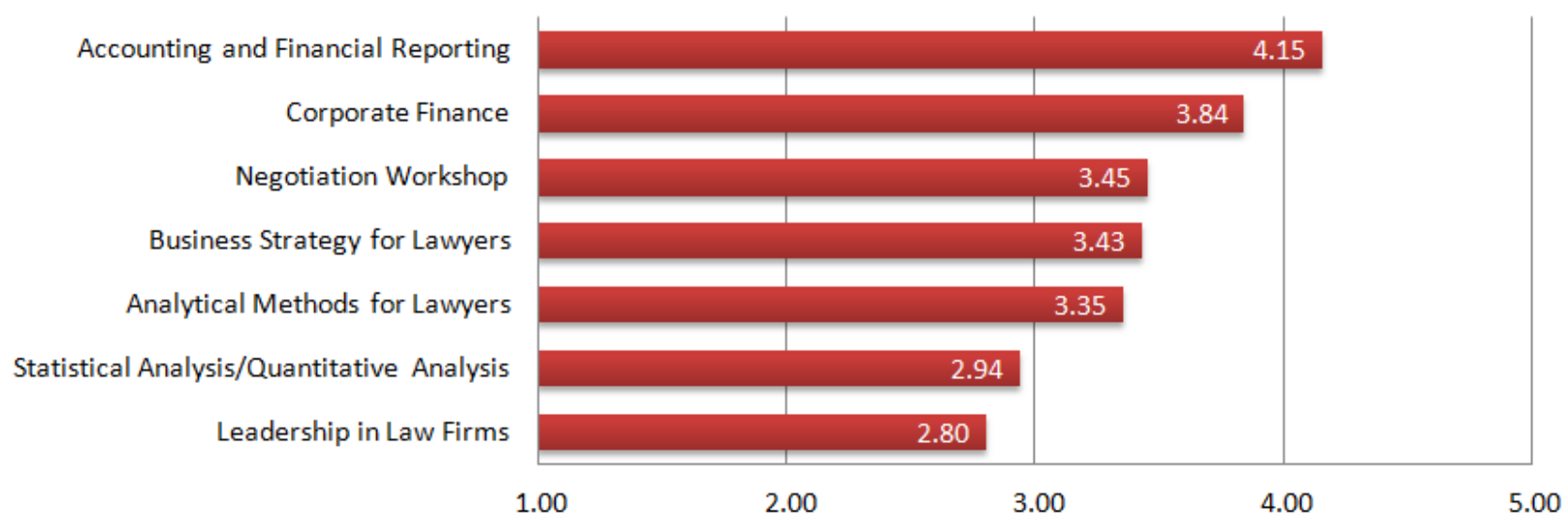

\section{Question \#2: Ranking Business-Methods Courses}

If you were advising an HLS student about which business methods class (or classes) to take, which three of the above classes would you suggest?

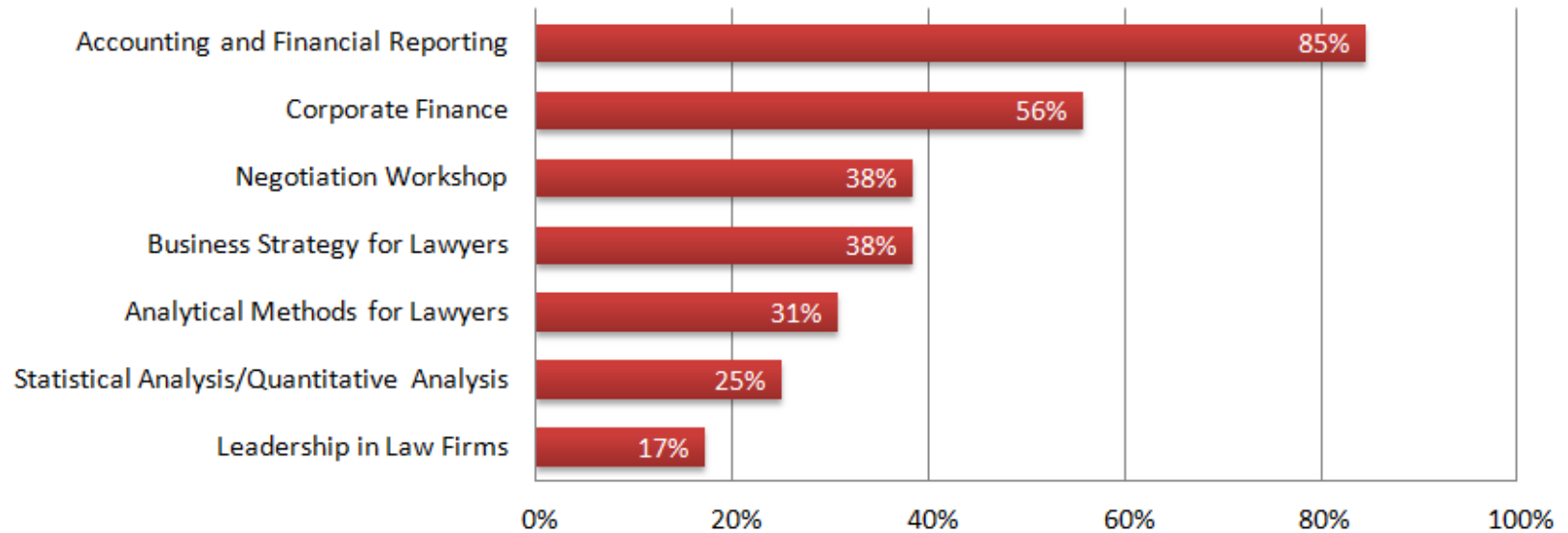




\section{Appendix A2: Litigation Practice Only $(\mathrm{N}=52)$}

\section{Question \#5: Rating Business Organizations Courses}

Below is a list of courses taught by regular Harvard faculty in the area of Business Organizations, Commercial Law, and Finance during the academic year 2012-2013. The list excludes all of the businessmethods courses described in the previous questions. Please indicate how useful it would be to an associate to have taken these courses. ( $1=$ Not at all Useful; $3=$ Somewhat Useful; $5=$ Extremely Useful)

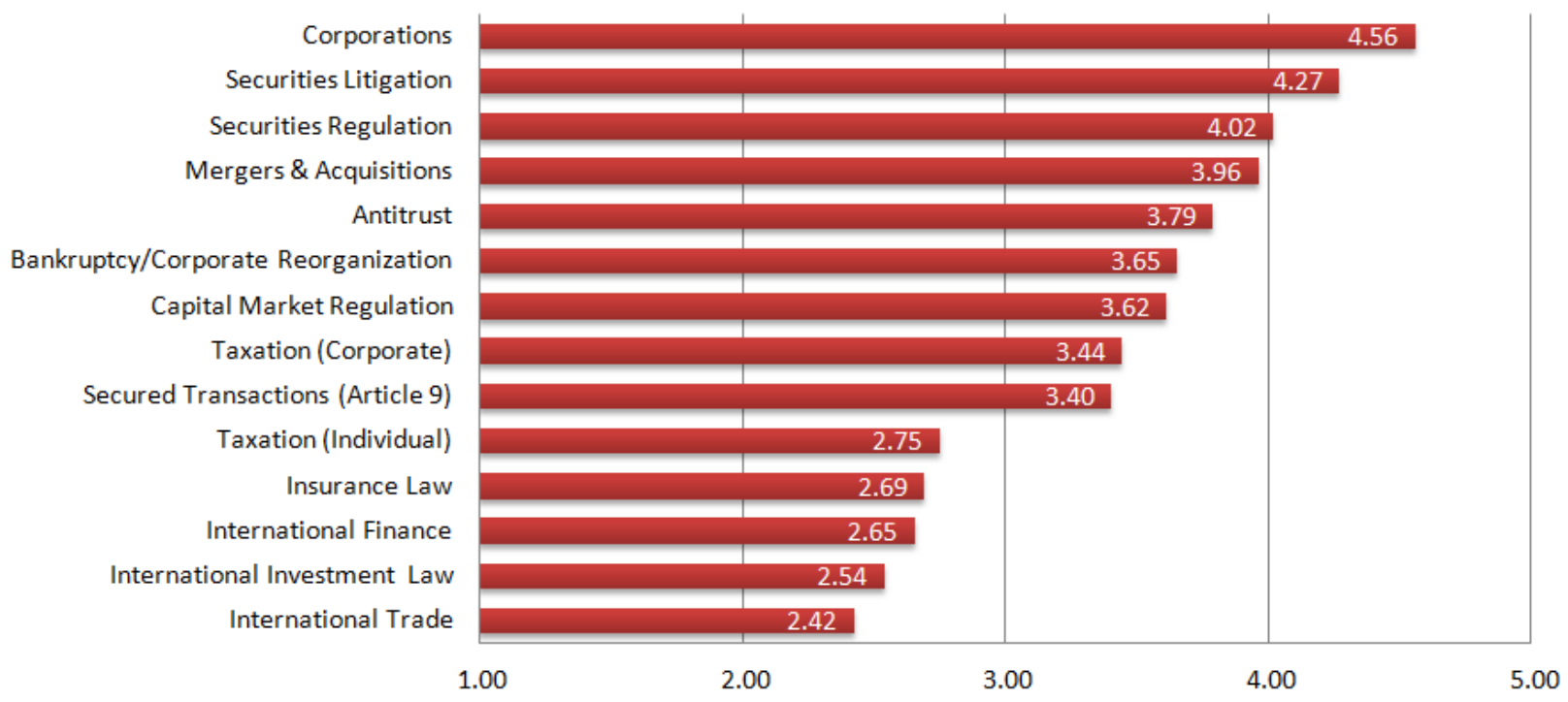

\section{Question \#6: Rating Non-BO Courses}

Below is a list of elective courses taught by regular Harvard faculty outside the area of Business Organization, Commercial Law, and Finance. Please indicate how useful it would be to an associate to have taken these elective courses. ( $1=$ Not at all Useful; $3=$ Somewhat Useful; $5=$ Extremely Useful $)$

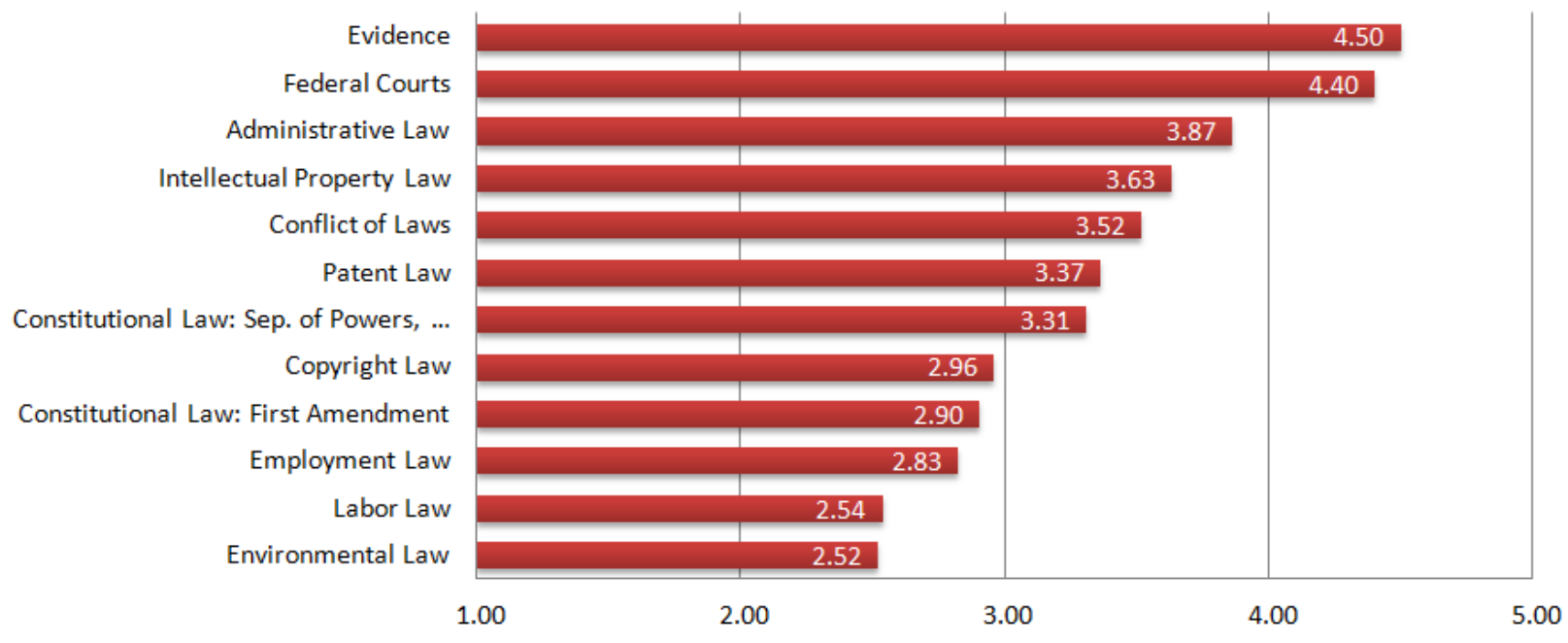




\section{Appendix A3: Corporate/Transactional Practice Only $(\mathrm{N}=50)$}

\section{Question \#1: Rating Business Methods Courses}

HLS has a variety of business methods course offerings that are geared towards students who have had little or no exposure to these areas. For each of the following existing HLS classes, please indicate how useful the course would be for an associate to have taken. $(1=$ Not at all Useful; 3 = Somewhat Useful; 5 $=$ Extremely Useful)

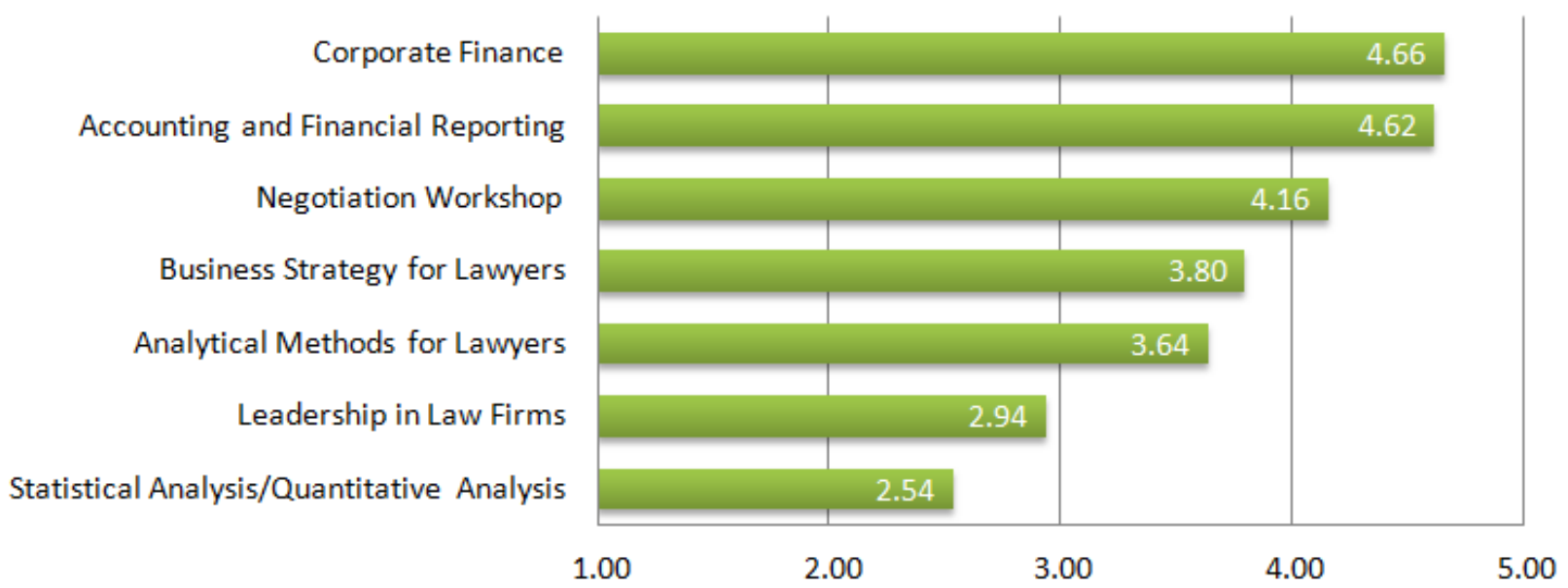

\section{Question \#2: Ranking Business Methods Courses}

If you were advising an HLS student about which business methods class (or classes) to take, which three of the above classes would you suggest?

Accounting and Financial Reporting

Corporate Finance

Negotiation Workshop

Business Strategy for Lawyers

Analytical Methods for Lawyers

Statistical Analysis/Quantitative Analysis

Leadership in Law Firms

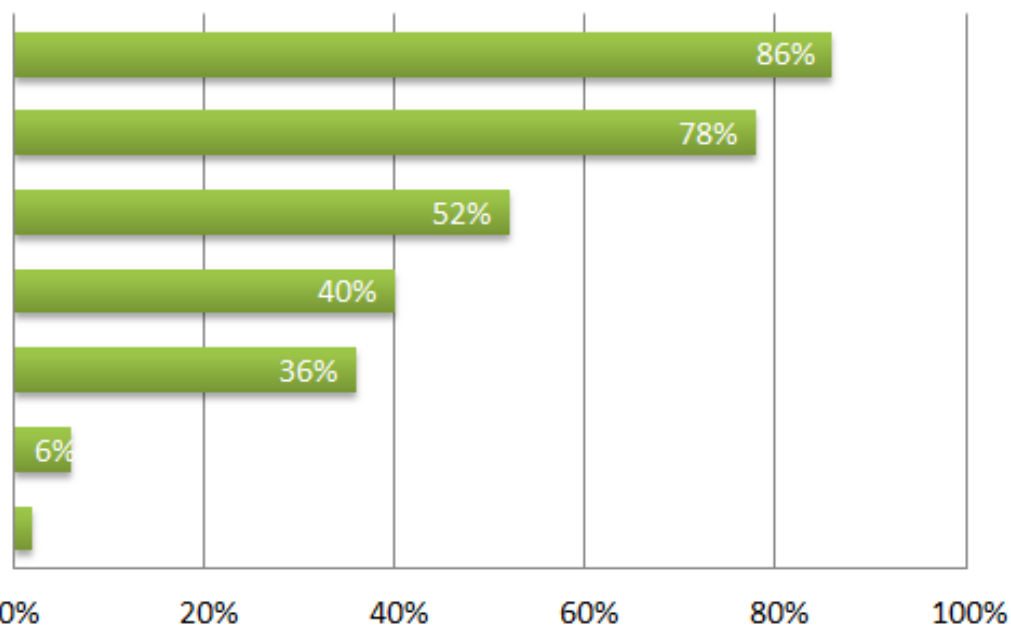




\section{Appendix A3: Corporate/Transactional Practice Only $(\mathrm{N}=50)$}

\section{Question \#5: Rating Business Organization Courses}

Below is a list of courses taught by regular Harvard faculty in the area of Business Organizations, Commercial Law, and Finance during the academic year 2012-2013. The list excludes all of the businessmethods courses described in the previous questions. Please indicate how useful it would be to an associate to have taken these courses. ( $1=$ Not at all Useful; $3=$ Somewhat Useful; $5=$ Extremely Useful)

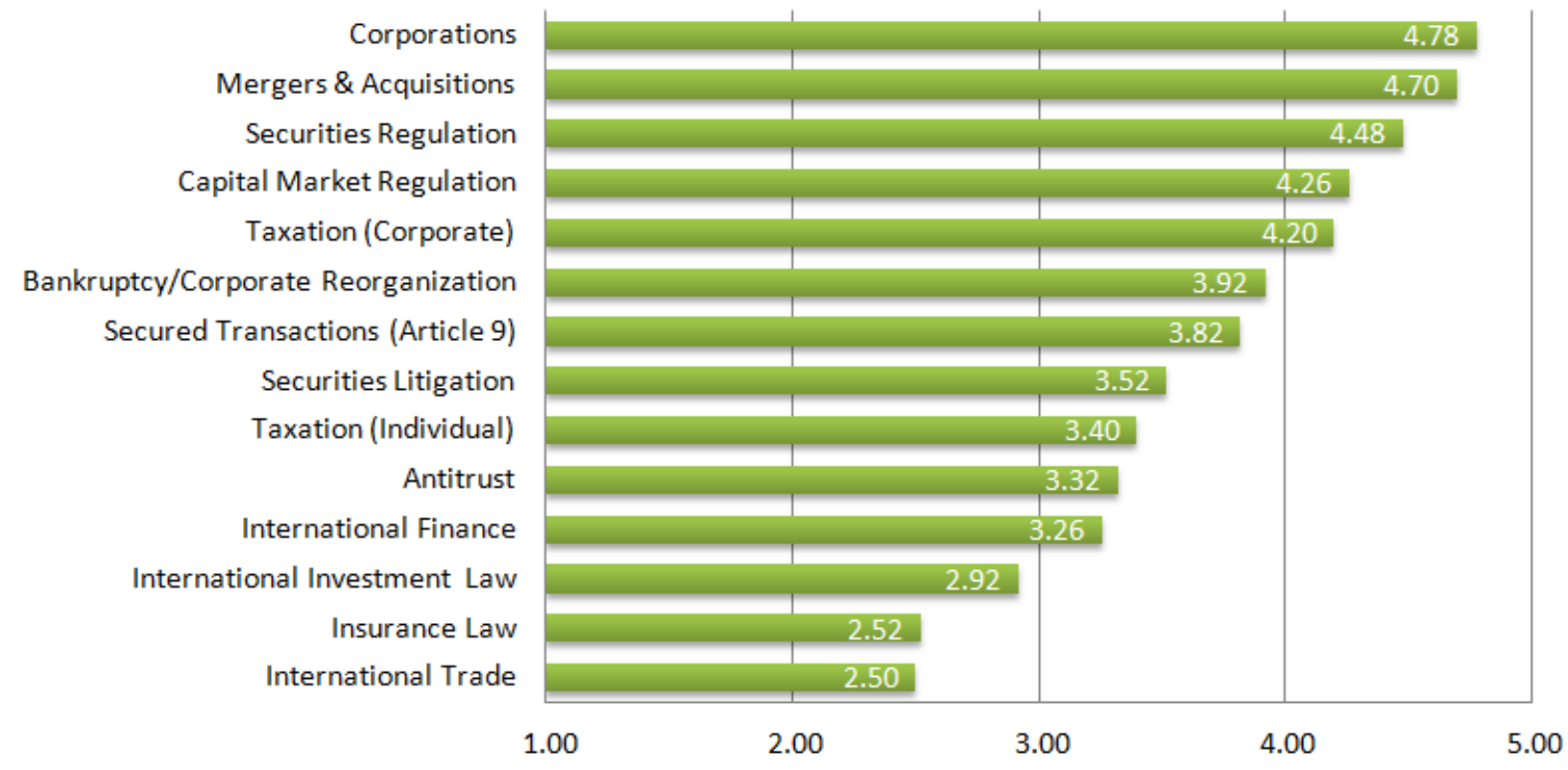

\section{Question \#6: Rating Non-BO Courses}

Below is a list of elective courses taught by regular Harvard faculty outside the area of Business Organization, Commercial Law, and Finance. Please indicate how useful it would be to an associate to have taken these elective courses. $(1=$ Not at all Useful; $3=$ Somewhat Useful; $5=$ Extremely Useful $)$

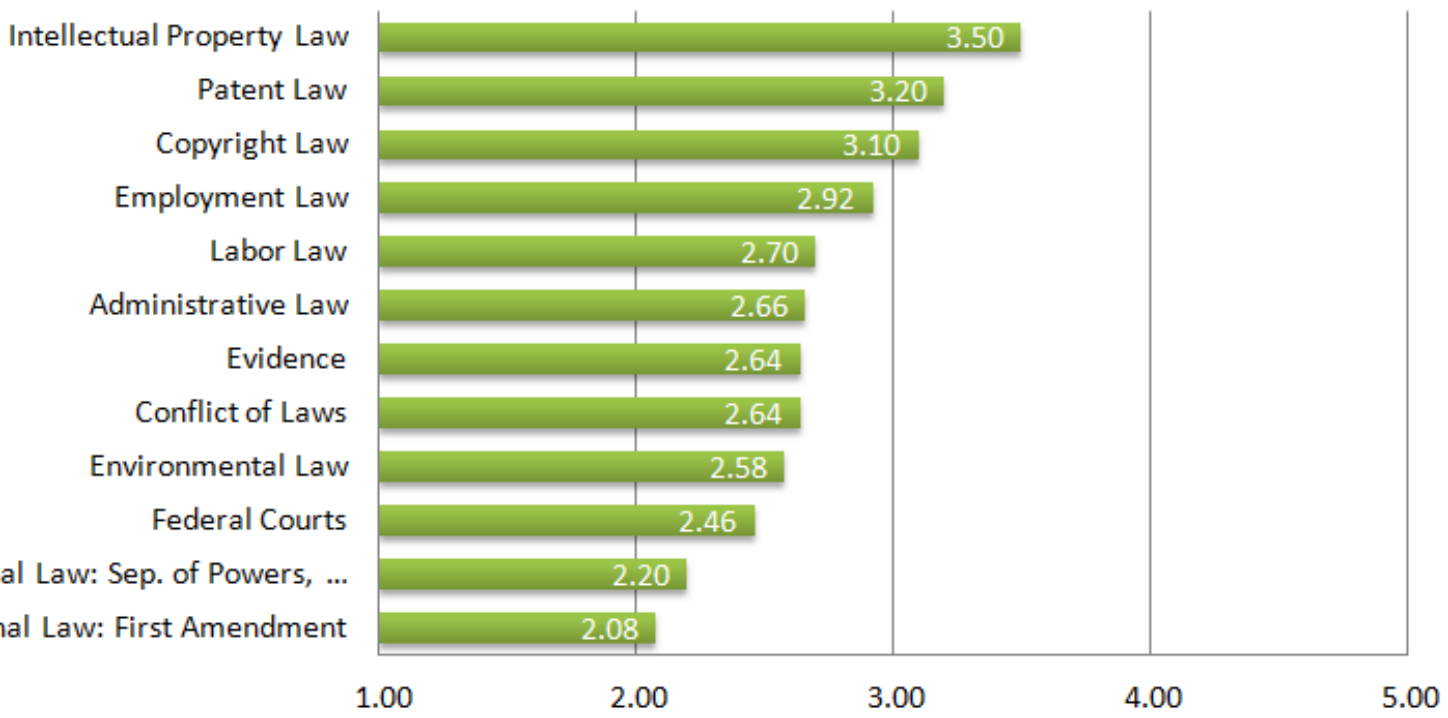




\section{APPENDiX B: HARVARd LaW SCHOOl EMPloyers' SURVEy (2013)}

\section{HARVARD \\ LAW SCHOOL}

\section{Harvard Law School's Employer Survey (2013)}

Thank you for participating in Harvard Law School's Employer Survey (2013). The purpose of this survey is to collect information from practicing attorneys that Harvard Law School (HLS) can use to better advise and train its students. You are being asked to participate in the survey because your law firm is one of the largest employers of HLS graduates.

The survey asks for your feedback on (1) the usefulness of various courses that HLS currently offers; (2) the desirability of adding certain courses; (3) the importance of various types of knowledge/skill bases to associates in your firm; and (4) any post-JD training that you have personally received or have recommended to others. The survey can be completed in about 10-15 minutes.

Much of the information gathered through this survey process will be disseminated to students to help them in course selection. All of the information will be used by HLS to improve the curriculum and guide staffing decisions. We would be happy to share the survey results with you when they are ready for distribution.

Your responses to this survey are anonymous. Any identifying information will be held in confidence. However, we would be very grateful if you were willing to share your contact information with us for follow-up purposes.

If you have any questions or comments about the survey, please do not hesitate to contact one of us.

Thank you again for participating. We look forward to receiving your feedback!

Best wishes,

John Coates (jcoates@law.harvard.edu)

Jesse Fried (jfried@law.harvard.edu)

Kathryn Spier (kspier@law.harvard.edu) 
Question \#1:

HLS has a variety of business-methods course offerings that are geared towards students who have had little or no exposure to these areas. For each of the following existing HLS classes, please indicate how useful the course would be for an associate to have taken. (Brief course descriptions are provided.)

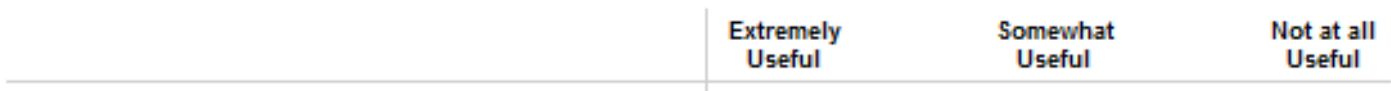

Accounting and Financial Reporting

This course is designed to help students develop an understanding of the accounting information presented in corporate financial statements. 2 classroom credits.

Analytical Methods for Lawyers

This course is designed to teach basic analytical methods to law students with problems set in legal contexts. Topics include Decision Analysis and Game Theory, Contracting (Fisk and Incentives), Accounting, Finance, Microeconomics, and Statistics. 3 or 4 classroom credits.

Business Strategy for Lawyers

This course presents the fundamentals of business strategy, including industry and competitor analysis, using lectures and business school case discussions. 3 classroom credits.

\section{Corporate Finance}

This course presents the fundamentals of financial economics as encountered in selected areas of comporate, bankruptcy, and securities law. 3 classroom credits.

\section{Leadership in Law Firms}

This course aims to help students understand law firms, as well as other professional service fims. The pnimary leaming tool is the business school case study method. 3 classroom credits.

\section{Negotiation Workshop}

Drawing on work from a variety of research perspectives, the readings and lectures provide students with a framework for analyzing negotiations and tools and concepts useful in negotiating more effectively. Participants spend much of their time in a series of negotiation exercises and also recejve personalized feedback. 4 classroom credits.

Statistical Analysis/Quantitative Analysis

This course provides basic tools needed for designing. conducting and critically assessing empinical legal research, i.e., legal research that relies on data-based argumentation. 1 classroom credit. 


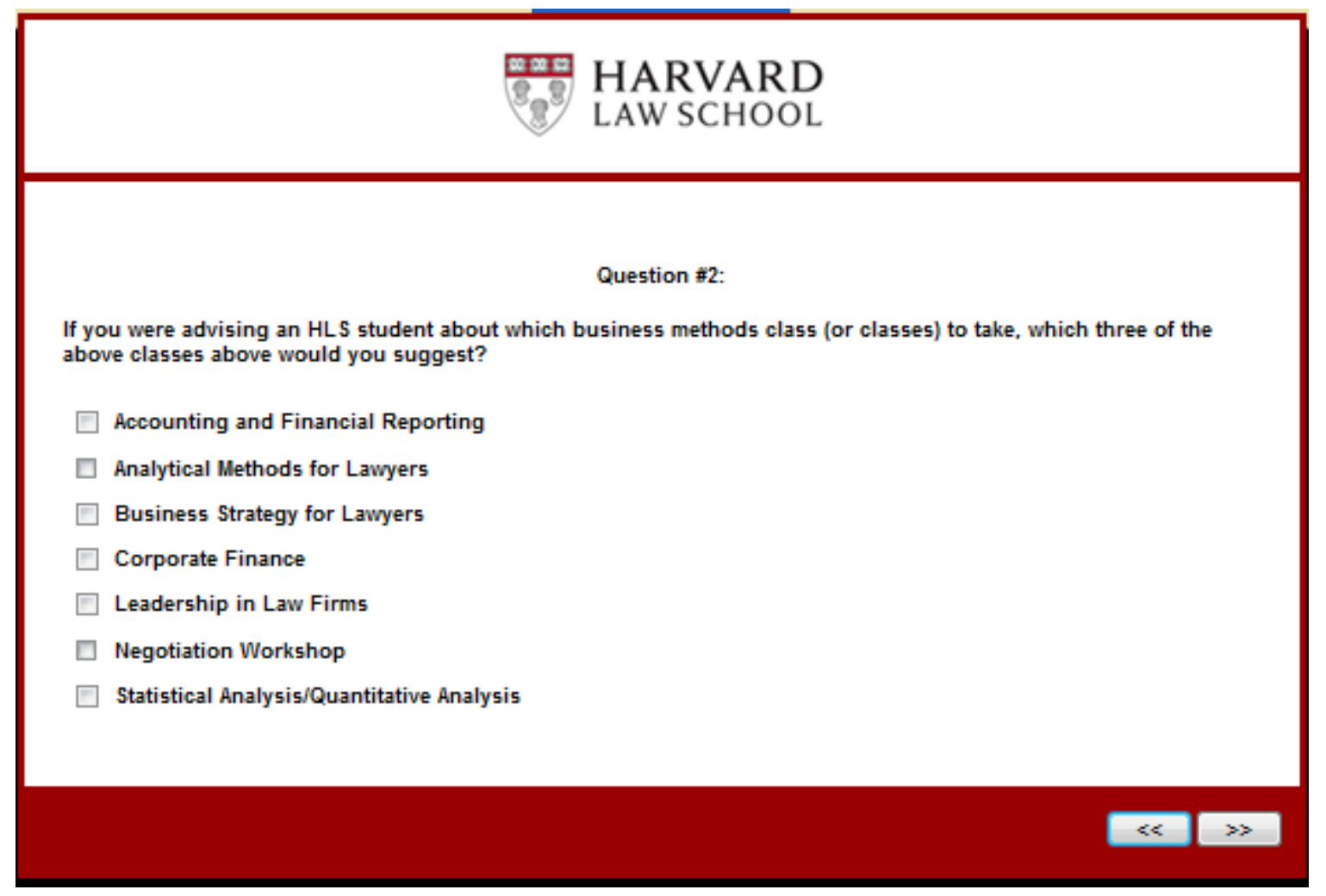




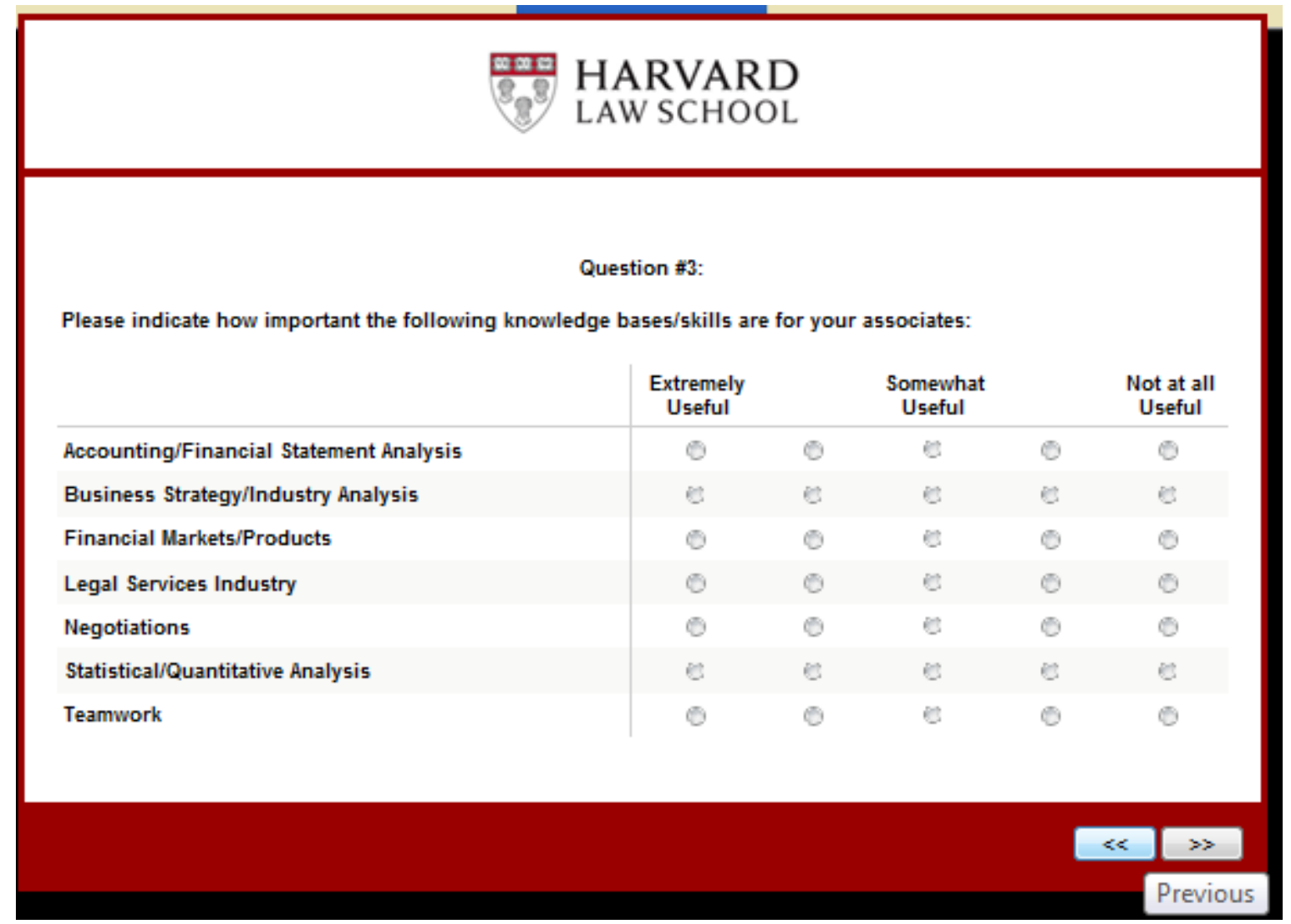




\section{HARVARD}

LAW SCHOOL

\section{Question \#4:}

There are several business methods courses, most of which are part of the first-year Harvard MBA curriculum, that are not currently offered at HLS but might be adopted by HLS. Which of the following classes, if any, do you think might be useful additions to the HLS curriculum?

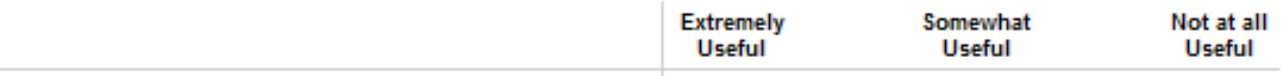

\section{Marketing}

The objectives of this course are to demonstrate the role of marketing in the company; to explore the relationship of marketing to other functions; and to show how effective marketing builds on a thorough understanding of buyer behavior to create value for customers.

\section{Business and Government}

This course introduces tools for studying the economic environment of business to help managers understand the implications for their companies. Topics include: National income and balance of payment accounting; Exchange rate theory; Political regimes Intemational trade; Foreign direct investment; Portfolio capital; Global environmental issues.

\section{Entrepreneurship}

This course addresses the issues faced by managers who wish to tum opportunity into viable organizations that create value. and empowers students to develop their own approaches, guidelines, and skills for being entrepreneunial managers.

Leadership and Corporate Accountability

In this course, students leam about the complex responsibilities facing business leaders today. Through cases about difficult managenal decisions, the course examines the legal, ethical, and economic responsibilities of comporate leaders. It also teaches students about management and govemance systems leaders can use to promote responsible conduct by companjes and their employees, and shows how personal values can play a critical role in effective leadership.

Technology and Operations Management

This course enables students to develop the skills and concepts needed to ensure the ongoing contribution of a firm's operations to its competitive position. It helps them to understand the complex processes underlying the development and manufacture of products as well as the creation and delivery of services.

\section{Valuation}

This course introduces students to how assets are valued. The course covers a wide range of assets (including public and private fims, debt, and equity) and the most commonly used valuation approaches (including discounted cash flow and relative valuation. 


\section{Question \#5:}

Below is a list of courses taught by regular Harvard faculty in the area of Business Organization, Commercial Law, and Finance during the academic year 2012-2013. The list excludes all of the business-methods courses described in the previous questions. Please indicate how useful it would be to an associate at your firm to have taken these courses.

\begin{tabular}{|c|c|c|c|c|c|}
\hline & $\begin{array}{c}\text { Extremely } \\
\text { Useful }\end{array}$ & & $\begin{array}{c}\text { Somewhat } \\
\text { Useful }\end{array}$ & & $\begin{array}{l}\text { Not at all } \\
\text { Useful }\end{array}$ \\
\hline Antitrust & $\odot$ & $\theta$ & $\odot$ & $e$ & 0 \\
\hline Bankruptcy/Corporate Reorganization & $e$ & es & $e$ & $\mathrm{c}$ & $e$ \\
\hline Capital Market Regulation & $\varnothing$ & $\theta$ & 0 & $\mathrm{e}$ & $\varnothing$ \\
\hline Corporations & $\odot$ & 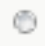 & 0 & $e$ & 0 \\
\hline Insurance Law & $\varnothing$ & 0 & $\theta$ & $\mathrm{e}$ & $\odot$ \\
\hline International Finance & $e$ & e & $e$ & $e$ & e \\
\hline International Investment Law & $\odot$ & 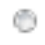 & $\odot$ & e & $\odot$ \\
\hline International Trade & $\odot$ & 0 & $\odot$ & e & $\odot$ \\
\hline Mergers \& Acquisitions & 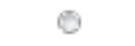 & 0 & $\odot$ & $\mathrm{c}$ & $\odot$ \\
\hline Secured Transactions (Article 9) & $e$ & $e$ & $e$ & $e$ & $e$ \\
\hline Securities Litigation & $\theta$ & $\odot$ & $\odot$ & $\mathrm{e}$ & 0 \\
\hline Securities Regulation & $\theta$ & 0 & $\odot$ & $\mathrm{e}$ & $\odot$ \\
\hline Taxation (Individual) & $\odot$ & 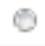 & $\odot$ & 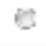 & $\odot$ \\
\hline Taxation (Corporate) & e & $e$ & $e$ & $e$ & $e$ \\
\hline
\end{tabular}




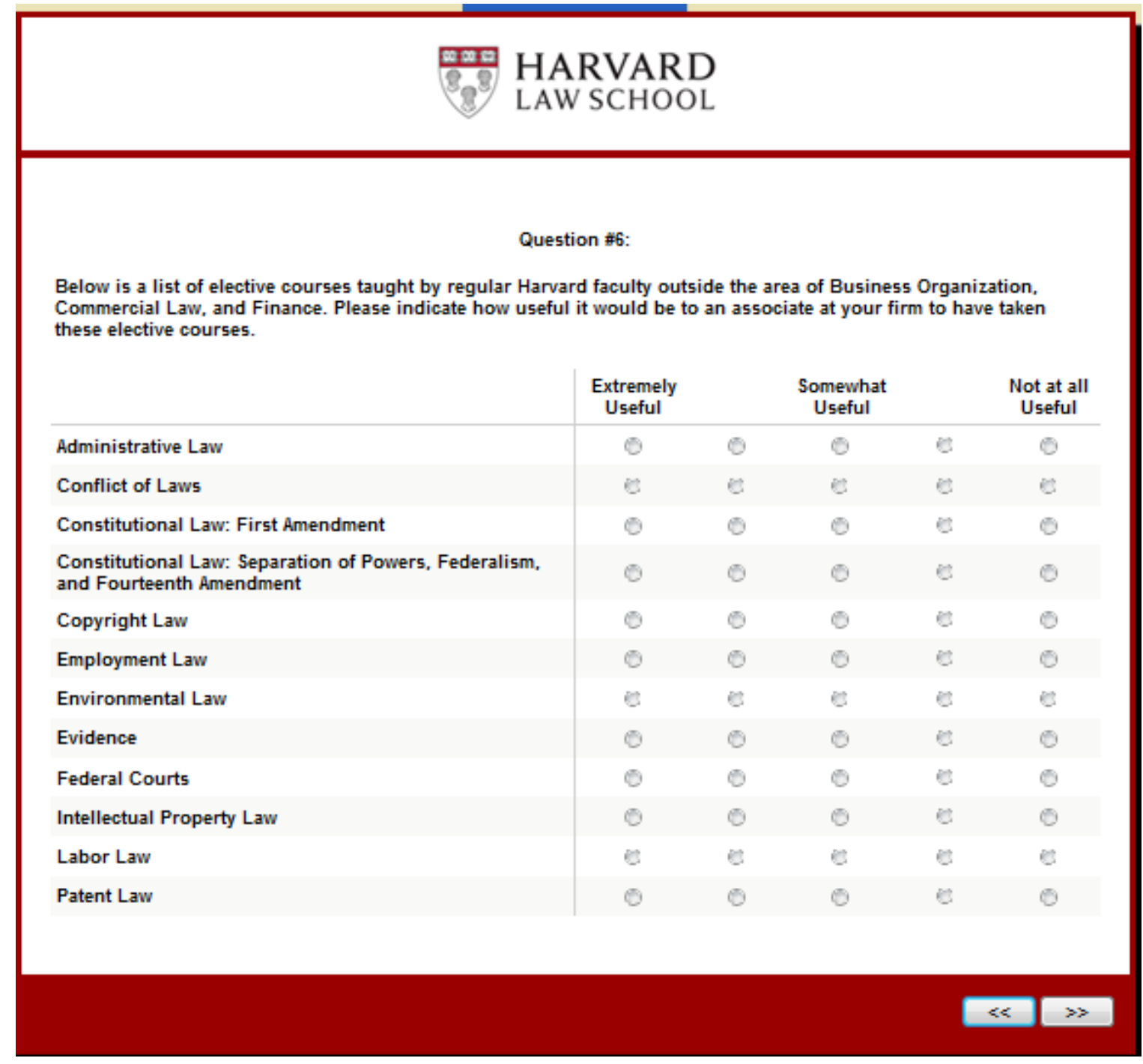


Question \#7:

(a) Have you have taken any continuing education or supplemental courses in the business-methods area?

No

C Yes

Describe:

(b) Are there any continuing education or supplemental courses, in the business-methods area, that you have recommended to others in your firm?

(Q) No

(1) Yes

Describe:

(c) Are there any in-house training programs, in the business-methods area, that your firm offers to its attorneys?

C No

Q Yes

Describe:

-1
-
-

(d) Are there any in-house training programs, in the business-methods area, that you would like to see your firm offer to its attorneys?

(4) No

Q Yes

Describe: 
PUBLIC VERSION

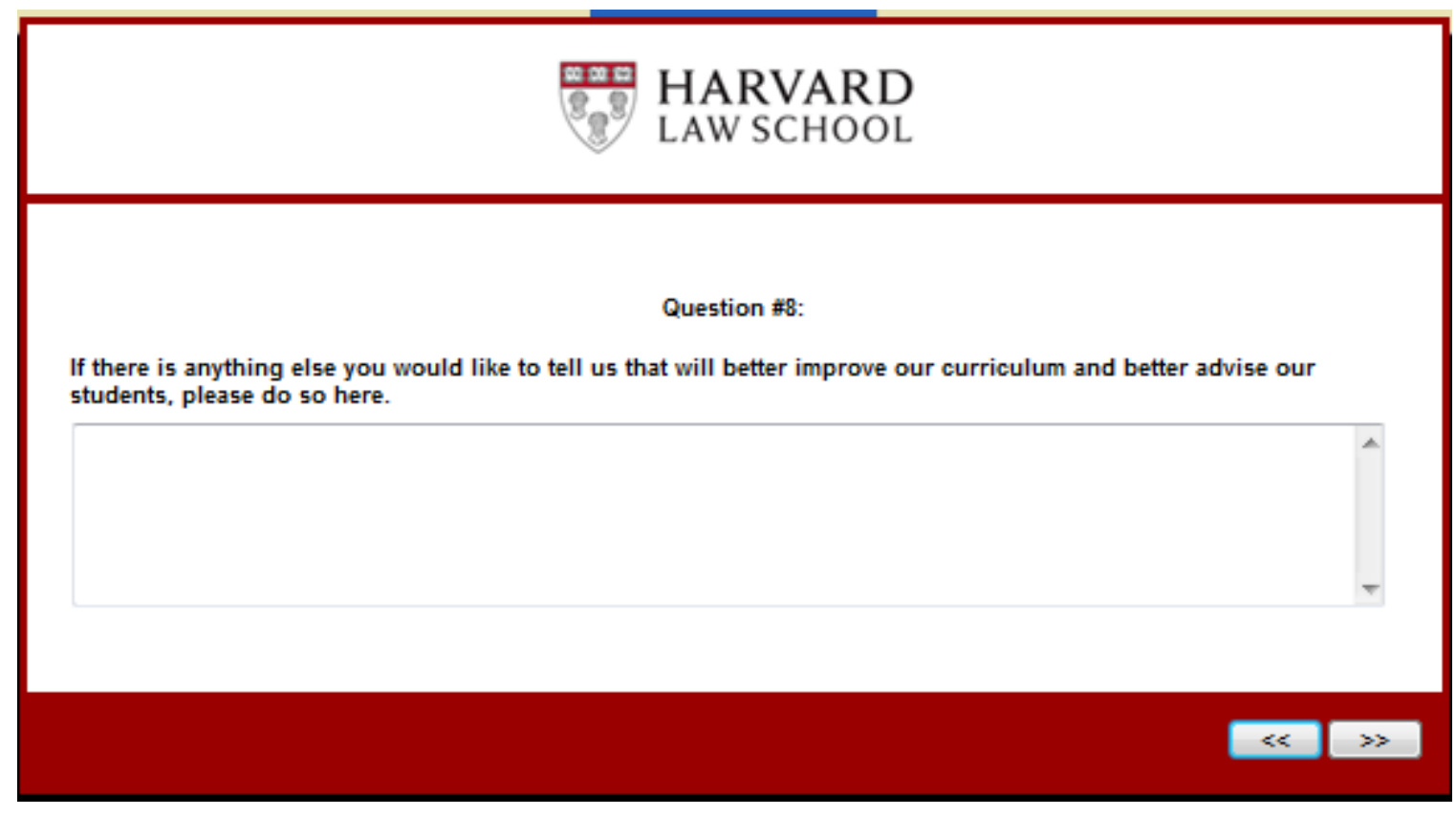


What is the name of your firm?

What is your rank within the firm?

C. Partner

(1) Associate

(4) Other (please specify)

Your department:

Corporate/Transactional

Q Litigation

Regulatory

Number of years with the firm:
0 - 5 years
5 - 10 years
10 - 20 years
20 - 30 years
$30+$ years

Would you would be willing to share your name and contact information with us? We may want to follow up with questions, and would very much appreciate your help in the future. If you are comfortable doing so, please enter your name and email address below.

This is the end of the survey. Once you click the forward button your responses will be submitted and you will not be able to change your answers.

THANK YOU VERY MUCH FOR PARTICIPATING!

rofessor John Coates; jcoates(Q)law.harvard.edu

Professor Jesse Fried; jfried@law.harvard.edu

Professor Kathryn Spier; kspier@law.harvard.edu 